\title{
Aftershock activity of Bhuj earthquake of January 26th, 2001
}

\author{
Ashwani Kumar, S C Gupta, A K Jindal, Sanjay Jain and Vandana \\ Department of Earthquake Engineering, Indian Institute of Technology Roorkee, Roorkee 247 667, India
}

Following a large-sized Bhuj earthquake $\left(M_{s}=7.6\right)$ of January 26th, 2001, a small aperture 4station temporary local network was deployed, in the epicentral area, for a period of about three weeks and resulted in the recording of more than 1800 aftershocks $\left(-0.07 \leq M_{L}<5.0\right)$. Preliminary locations of epicenters of 297 aftershocks $\left(2.0 \leq M_{L}<5.0\right)$ have brought out a dense cluster of aftershock activity, the center of which falls $20 \mathrm{~km} \mathrm{NW}$ of Bhachau. Epicentral locations of aftershocks encompass a surface area of about $50 \times 40 \mathrm{~km}^{2}$ that seems to indicate the surface projection of the rupture area associated with the earthquake. The distribution of aftershock activity above magnitude 3, shows that aftershocks are nonuniformly distributed and are aligned in the north, northwest and northeast directions. The epicenter of the mainshock falls on the southern edge of the delineated zone of aftershock activity and the maximum clustering of activity occurs in close proximity of the mainshock. Well-constrained focal depths of 122 aftershocks show that $89 \%$ of the aftershocks occurred at depths ranging between 6 and $25 \mathrm{~km}$ and only $7 \%$ and $4 \%$ aftershocks occur at depths less than 5 and more than $25 \mathrm{~km}$ respectively. The Gutenberg-Richter (GR) relationship, $\log N=4.52-0.89 M_{L}$, is fitted to the aftershock data $\left(1.0 \leq M_{L}<5.0\right)$ and the $b$-value of 0.89 has been estimated for the aftershock activity.

\section{Introduction}

The Kachchh basin extends for about $250 \mathrm{~km}$ in the eastwest direction and $150 \mathrm{~km}$ in the northsouth direction and is bounded by two major faults namely, the Nagar Parker fault in the north and the Kathiawar fault in the south. The basin is marked by the presence of several other eastwest trending tectonic features viz., Katrol Hill Fault, Vigodi Fault, Kachchh Mainland Fault, Banni Fault, Wagad Fault, Island Belt Fault and Allah Bund Fault. Throughout the Cenozoic period the region has experienced several episodes of tectonic deformations along the major eastwest trending faults. These deformations have contributed both to the evolution of the present day landscape and accentuated the structural pattern of the region (Biswas 1971; Malik et al 1999).

Many devastating earthquakes have occurred in the region in the past. Notable among these are the Samaji town $\left(25^{\circ} \mathrm{N}, 68^{\circ} \mathrm{E}\right)$ earthquake of May 1668 (maximum MMI intensity X), the Rann of Kachchh earthquake of June 16th, 1819 (MMI intensity XI and $M_{w} 7.8$ ), the Lakpat earthquake of April 19th, 1845 (MMI intensity VIII) and the Anjar earthquake of July 21st, 1956 (MMI intensity IX and $M_{w} 6.0$ ) (Tandon 1959; Chandra 1977; Chung and Gao 1995). The great Kachchh earthquake produced the first evidence of faulting in the form of eighty kilometers long scarp with a maximum height of about $6 \mathrm{~m}$ (Richter 1958).

The Bhuj earthquake of January 26th, 2001 was followed by intense aftershock activity that spans the magnitude range from less than zero to 5.7. The India Meteorological Department (IMD) reported 458 aftershocks having a magnitude three and above up to February 28th, 2001. To monitor the aftershock activity associated with this earthquake, the Department of Earthquake Engineering installed a small aperture 4-station temporary

Keywords. Bhuj earthquake; aftershocks; local network; temporal distribution; $b$-value. 
Table 1. Geographical coordinates of recording stations and duration of recording.

\begin{tabular}{llcccc}
\hline Sl. & & Station & \multicolumn{2}{c}{ Location } & \\
no. & Station name & code & Lat. $\left({ }^{\circ} \mathrm{N}\right)$ & Long. $\left({ }^{\circ} \mathrm{E}\right)$ & \multicolumn{2}{c}{ Recording duration } \\
\hline 1. & Maliya & MLY & 23.10 & 70.78 & 8 days (February 4th-11th) \\
2. & Samakhyari & SHM & 23.30 & 70.50 & 18 days (February 11th-28th) \\
3. & Pragpar & PRG & 22.90 & 69.71 & 24 days (February 5th-28th) \\
4. & Deshalpar & DLP & 23.19 & 69.45 & 23 days (February 6th-28th) \\
5. & Khavda & KVD & 23.83 & 69.74 & 21 days (February 8th-28th) \\
\hline
\end{tabular}

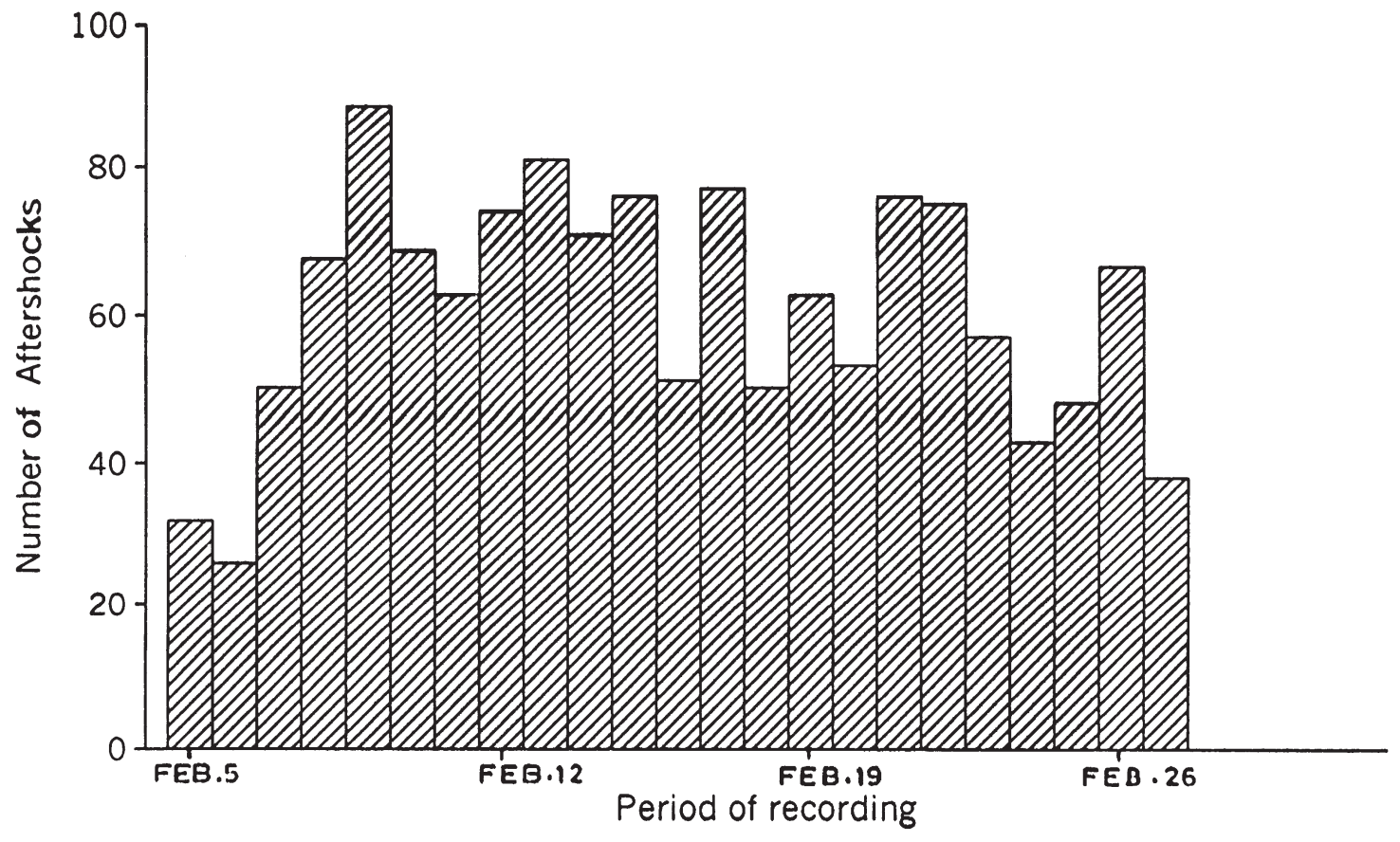

Figure 1. Daily frequency of aftershocks $\left(M_{L} \geq 1\right)$ from February 5 th to February 27th, 2001.

local network around the epicentral area. The network stations were operated for a period of 25 days from February 4th to February 28th, 2001 at five locations namely, Maliya (MLY), Pragpar (PRG), Deshalpar (DLP), Khavda (KVD) and Samakhyari (SHM). However, simultaneous recording at four stations was conducted for a period of three weeks (table 1). The equipment used for recording consisted of microearthquake recorders (MEQ-800B) coupled to short period vertical component seismometers. The recording was carried out at a speed of $120 \mathrm{~mm} / \mathrm{min}$ and 202 seismograms were obtained. Scanning of seismograms resulted in the identification of more than 1800 aftershocks $\left(-0.07 \leq M_{L}<5.0\right)$. The present study describes the preliminary results obtained on the basis of analysis of the aftershock data.

\section{Temporal distribution of aftershock activity}

Out of 1800 aftershocks in the magnitude $\left(M_{L}\right)$ range between -0.07 and 5.0, about 1400 after- shocks fall in the magnitude range between 1.0 and 5.0. A histogram of daily frequency of occurrence of aftershock activity $\left(M_{L} \geq 1\right)$ recorded for a period of 23 days is shown in figure 1 . From February 5th to February 27th the recording was done continuously whereas, on February 4th and February 28th the recording was done for a few hours only. During this period the frequency of aftershocks $\left(M_{L} \geq 1\right)$ varies from 27 events per day to about 89 events per day and activity does not show decay with time. There were more than 1000 events having $1 \leq M_{L}<2$, about 323 events between magnitude 2 and 3 , and 71 events having $M_{L} \geq 3$.

\section{Locations of aftershocks}

Hypocenter parameters of aftershocks were estimated employing HYPO71PC computer program and using the two layers crustal velocity model (Tandon and Chaudhury 1968; Lee \& Lahr 1975). Due to 4 -station network, $S$-phase arrival time data was also used in addition to $P$-phase arrival time 


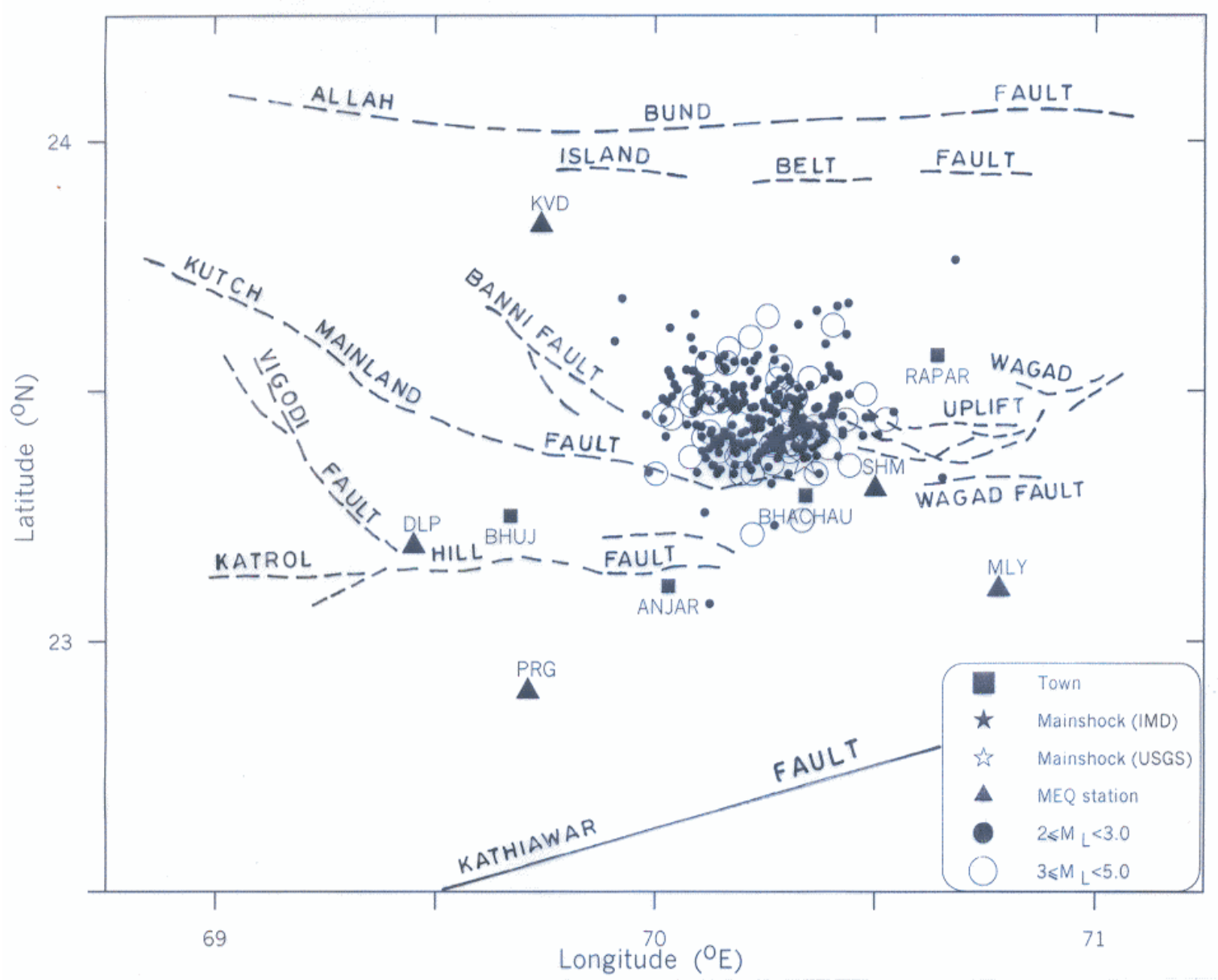

Figure 2(a). Epicenters of aftershocks $\left(M_{L} \geq 2\right)$ of Bhuj earthquake, January 26th, 2001.

data to allow estimation of standard errors in the hypocenter parameters. Preliminary locations of epicenters of 297 aftershocks $\left(2 \leq M_{L}<5.0\right)$ have brought out a dense cluster of activity in the close proximity of the mainshock epicenter. The center of the cluster falls $20 \mathrm{~km}$ NW of Bhachau (figure 2a). The epicenters of aftershocks encompass a surface area with dimensions of about $50 \times 40 \mathrm{~km}^{2}$ that seems to indicate the surface projection of the rupture area associated with the earthquake. The distribution of activity with $M_{L} \geq 3$, as shown in figure 2(b), is nonuniform in nature and primarily defines two main zones of aftershocks aligned in the north and northwest directions. The zone aligned in the north direction is about $25 \mathrm{~km}$ in length and the aftershocks aligned in the northwest direction over a length of about $30 \mathrm{~km}$. In addition there are two weak zones of aftershocks aligned in the northeast direction. The surface area of $50 \times 40 \mathrm{~km}^{2}$ is by and large in agreement with the fault area of $1661 \mathrm{~km}^{2}$ (Bhattacharaya et al 2001). The epicenters of aftershocks obtained in this study, are comparable with those reported by
Rastogi et al (2001) and by CERI, Memphis, USA (2001).

The clusters of epicenters of aftershocks seem to indicate the secondary redistribution of stresses due to primary failure on the fault (Mendoza and Hartzell 1988). The distribution of aftershocks shows NP2-strike $60^{\circ}$, dip $58^{\circ}$, slip $56^{\circ}$ (Bhattacharaya et al 2001) as the most likely fault plane.

\section{Focal depth distribution}

The focal depth distribution of 122 aftershocks $\left(2 \leq M_{L}<5.0\right)$ with well constrained focal depths having standard errors in focal depth $\leq 5 \mathrm{~km}$ shows that about $89 \%$ of aftershocks occur at depths between 6 and $25 \mathrm{~km}$ and only $7 \%$ and $4 \%$ aftershocks occur in the depth range up to $5 \mathrm{~km}$ and above $25 \mathrm{~km}$ respectively. The focal depths obtained in this study are shallow in comparison to those reported in other studies (Rastogi et al 2001; CERI, Memphis, USA 2001). The observed 


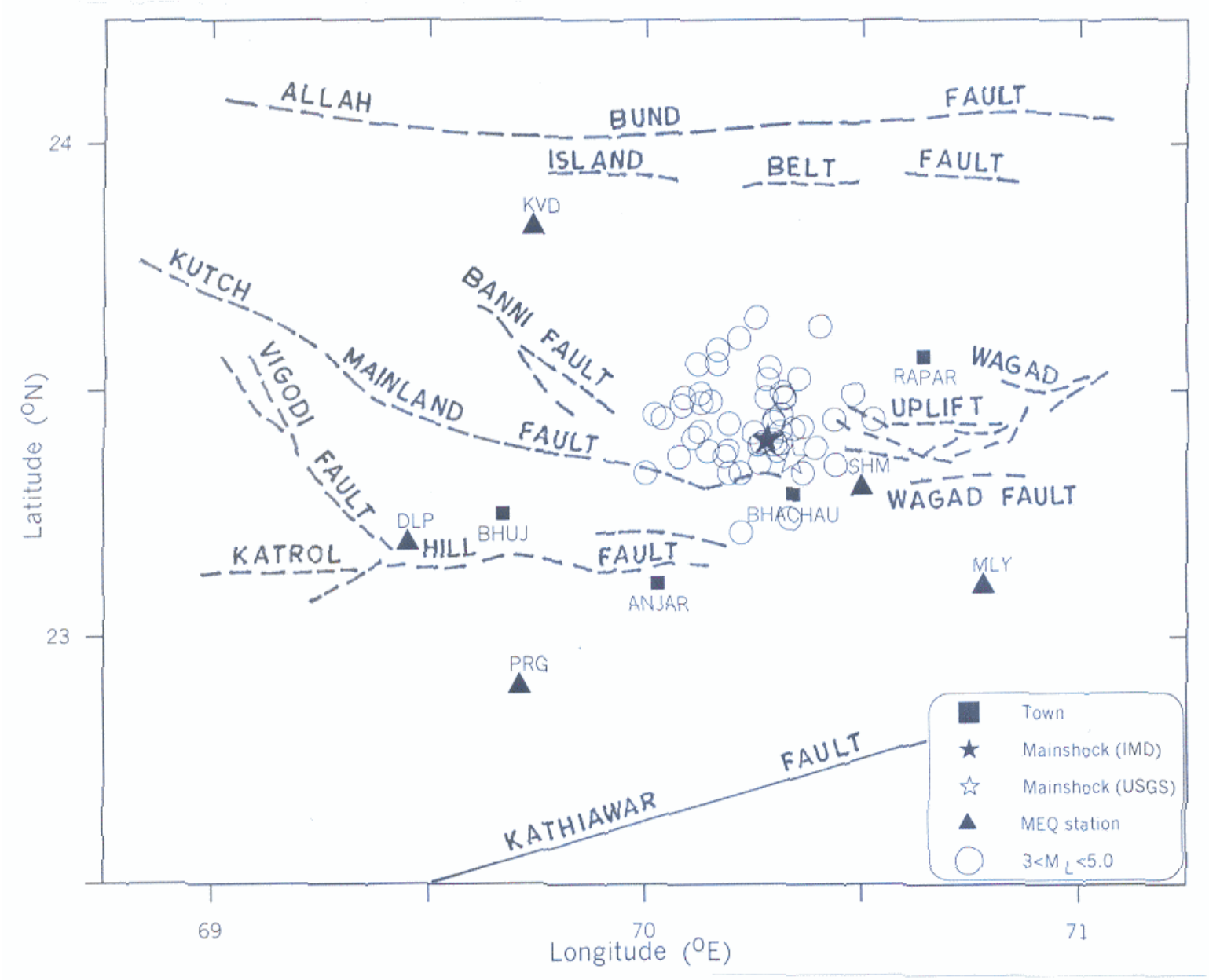

Figure 2(b). Epicenters of aftershocks $\left(M_{L} \geq 3\right)$ of Bhuj earthquake, January 26th, 2001.

difference in focal depths may be due to different velocity models and other factors influencing the estimation of hypocenter parameters including the period of recording.

\section{Frequency-magnitude relationship}

A histogram, giving the frequency distribution of aftershocks $\left(M_{L} \geq 1\right)$ with magnitudes, is drawn by grouping events in the magnitude class interval of 0.4 (figure 3a). The plot depicts that the frequency of aftershocks decreases as magnitude increases and about $95 \%$ aftershocks occur in the magnitude range of $1.0 \leq M_{L}<3.0$. Only $5 \%$ of aftershocks occur above magnitude 3 . Considering this data set $\left(1.0 \leq M_{L}<5.0\right)$, a Gutenberg-Richter (GR) recurrence relationship, $\log N=4.52-0.89 M_{L}$, (figure $3 \mathrm{~b}$ ) is fitted employing least-square technique and the $b$-value of 0.89 has been estimated for the aftershock activity.

\section{Conclusions}

The following broad conclusions are drawn from this study:

- The Bhuj earthquake of January 26th, 2001 was followed by intense aftershock activity and more than 1800 aftershocks $\left(-0.07 \leq M_{L}<5.0\right)$ were recorded for a period of 25 days from February 4th to February 28th, 2001. Temporal distribution does not show decay of aftershock activity with time during the period of observation.

- The epicenters of 297 aftershocks $\left(2 \leq M_{L}\right.$ $<5.0$ ) encompass a surface area of $50 \times 40 \mathrm{~km}^{2}$. This seems to be the surface projection of fault rupture area associated with the earthquake. The locations of aftershocks $\left(M_{L} \geq 3\right)$ have brought out two prominent alignments of cluster in the north and northwest of the epicenter of the mainshock having a length of $25 \mathrm{~km}$ and $30 \mathrm{~km}$ respectively.

- Well constrained focal depths of 122 aftershocks $\left(2 \leq M_{L}<5.0\right)$ show that about $89 \%$ after- 

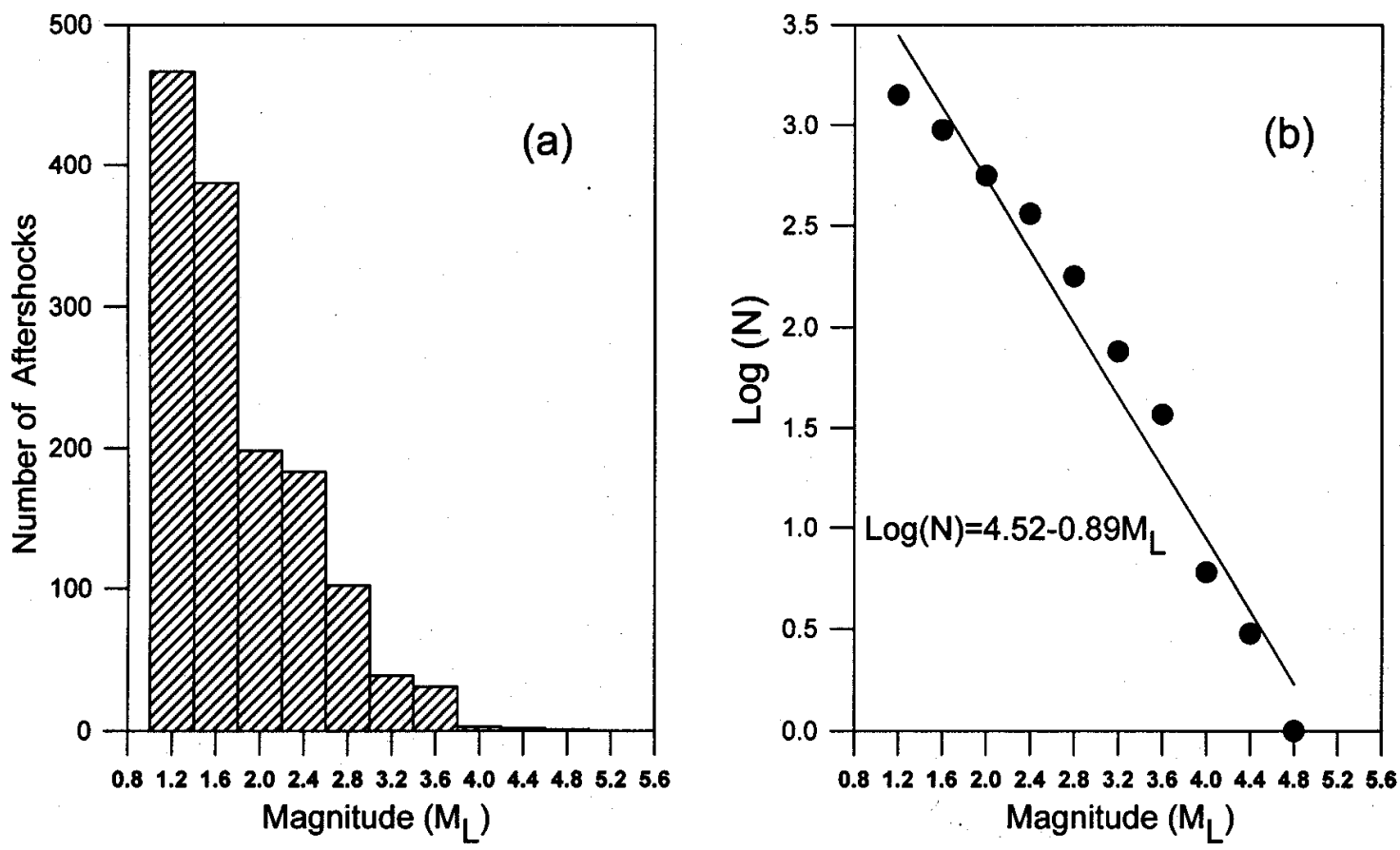

Figure 3. (a) Frequency distribution of aftershock activity with magnitude and (b) Gutenberg-Richter recurrence curve for the aftershock activity.

shocks occur at depths between 6 and $25 \mathrm{~km}$. The $b$-value of 0.89 has been estimated for the aftershock activity.

\section{Acknowledgements}

Financial support to carry out the study became available from the Department of Science and Technology, Seismology Division, New Delhi. Authors are thankful to the Head, Department of Earthquake Engineering, for extending facilities to carry out the study.

\section{References}

Biswas S K 1971 Note on the Geology of Kachchh: India Geol.; Min. Metall. Soc. Quart. Jour. 43 223-235

Bhattacharya S N, Dattatrayam R S, Shukla A K, Baidya P R and Suresh G 2001 Source parameters of Bhuj earthquake of January 26, 2001; workshop on recent earthquake of Chamoli and Bhuj, May 24-26, 2001, Roorkee

CERI, Memphis, USA 2001 Preliminary study on Bhuj aftershock data
Chandra U 1977 Earthquakes of peninsular India A seismotectonic study; Bull. Seism. Soc. Am. 67 $1387-1413$

Chung W Y and Gao H 1995 Source parameters of Anjar earthquake of July 21, 1956, India and its seismotectonic implications for the Kachchh rift basin; Tectonophysics 242 281-292

Lee W H K and Lahr J C 1975 HYPO71: A computer program for determining hypocenter, magnitude and first motion pattern of local earthquakes. USGS Open File Report, 75-311, 1-116

Malik J N, Sohoni P S, Karanth R V, Merh S S 1999 Modern and historic seismicity of Kachchh Peninsula, western India; Jour. Geolog. Soc. 54 545-550

Mendoza C and Hartzell S H 1988 Aftershock patterns and mainshock faulting; Bull. Seis. Soc. Am. $\mathbf{7 8}$ $1438-1449$

Rastogi B K, Mandal P, Satyamurty C, Kumar N and Nageshwar Rao A 2001 Ground deformation, damage pattern and aftershock study of 2001 Bhuj earthquake; workshop on recent earthquake of Chamoli and Bhuj, May 24-26, 2001, Roorkee., 51-60

Richter C F 1958 Elementary Seismology (San Francisco, California: W.H. Freeman and Co., Inc.)

Tandon A N 1959 The Rann of Cutch earthquake of July 21, 1956; Indian J. Meteorol. Geophys. 10 137-146

Tandon A N and Chaudhury H M 1968 Koyna earthquake of December 1967. Sci. Rep. Ind. Met. Dept., No. 59: $1-12$ 